\title{
molecules
}

ISSN 1420-3049

www.mdpi.com/journal/molecules

Article

\section{Synthesis and Pharmacological Evaluation of Modified Adenosines Joined to Mono-Functional Platinum Moieties}

Stefano D'Errico ${ }^{1}$, Giorgia Oliviero ${ }^{1, *}$, Nicola Borbone ${ }^{1}$, Vincenzo Piccialli ${ }^{2}$, Brunella Pinto ${ }^{1}$, Francesca De Falco ${ }^{1}$, Maria Chiara Maiuri ${ }^{1,3}$, Rosa Carnuccio ${ }^{1}$, Valeria Costantino ${ }^{1}$, Fabrizia Nici ${ }^{1}$ and Gennaro Piccialli ${ }^{1}$

1 Dipartimento di Farmacia, Università degli Studi di Napoli "Federico II", via D. Montesano, 49, 80131 Napoli, Italy; E-Mails: stefano.derrico@unina.it (S.D.); borbone@unina.it (N.B.); brunella.pinto87@gmail.com (B.P.); francesca.defalco@unina.it (F.D.F.); mariachiara.maiuri@unina.it (M.C.M.); rosa.carnuccio@unina.it (R.C.); valeria.costantino@unina.it(V.C.); fabrizia.nici@unina.it (F.N.); picciall@unina.it (G.P.)

2 Dipartimento di Scienze Chimiche, Università degli Studi di Napoli "Federico II", via Cintia, 21, 80126 Napoli, Italy; E-Mail: vinpicci@unina.it

3 INSERM U848, IGR, 39 rue C. Desmoulins, 94805 Villejuif, France

* Author to whom correspondence should be addressed; E-Mail: golivier@unina.it; Tel.: +39-081-679-896.

Received: 26 March 2014; in revised form: 23 June 2014 / Accepted: 25 June 2014 / Published: 3 July 2014

\begin{abstract}
The synthesis of four novel platinum complexes, bearing $N^{6}$-(6-aminohexyl)adenosine or a 1,6-di(adenosin- $N^{6}$-yl)-hexane respectively, as ligands of monofunctional cisplatin or monochloro(ethylendiamine)platinum(II), is reported. The chemistry exploits the high affinity of the charged platinum centres towards the N7 position of the adenosine base system and a primary amine of an alkyl chain installed on the C6 position of the purine. The cytotoxic behaviour of the synthesized complexes has been studied in A549 adenocarcinomic human alveolar basal epithelial and MCF7 human breast adenocarcinomic cancer cell lines, in order to investigate their effects on cell viability and proliferation.
\end{abstract}

Keywords: platinum complexes; nucleosides; cisplatin; chemotherapy 


\section{Introduction}

The discovery of the anti-proliferative properties of cisplatin [1] marked the beginning of modern chemotherapy based on the use of metal complexes capable of blocking the replication of cancer cells targeting the nuclear DNA [2,3]. In fact, it is widely accepted that cisplatin, once inside the cell, may form a highly reactive species [4,5] that can react with DNA through the formation of intra-strand linkages [6,7]. Such linkages alter the secondary structure of DNA, resulting in an inhibition of transcription and replication, ultimately leading to cell death [4]. However, the poor solubility in biological fluids [8], the serious side effects [9,10], and, more importantly, the intrinsic and acquired resistance of many types of tumors [5], have limited its use in the clinic. Carboplatin and oxaliplatin, second and third generation anti-neoplastic agents, respectively, are able to enhance the quality of life of patients in terms of dosage and drug administration. However, they can still trigger mechanisms of resistance (intrinsic and/or acquired) during repeated cycles of oncological treatment [5]. It was then discovered that the presence of more charged metal centres separated by unbranched alkylamine chains leads to complexes capable of being uptaken by cells via active import [11] and of overcoming the intrinsic and/or acquired resistance in some tumors [6,12-15]. Based on the understanding that they may exert anti-tumoral activities through inter-strand linkages with DNA that cannot be repaired by enzymes [16], many multinuclear platinum complexes have recently been synthesized, by varying the diamine backbone chain length, or by introducing modified linkers [8,10-12,17,18]. In addition, new Pt-based compounds have been obtained by conjugating biologically important substances or drugs to Pt-containing subunits [19-24] and novel drug-delivery based methodologies have been explored to vehiculate platinum-based anti-cancer complexes directly against tumors $[25,26]$.

Nucleoside and nucleotide anti-metabolites and their base analogues are able to inhibit specific pathways of the cancer cell metabolism by blocking the biosynthesis or the function of nucleic acids. For example, the combination of cisplatin and 5-fluorouracil, a chemotherapeutic agent that inhibits thymidylate synthase, has been extensively used in clinical practice to treat various types of cancer. Acyclovir, a guanosine nucleoside analogue containing an open-chain sugar surrogate, has been used as a ligand for platinum and the corresponding complex exhibits high in vitro activity against various herpes viruses [27]. Furthermore, the synthesis and the preliminary pharmacological activity of novel modified adenosines and thymidines, employed as N-donor ligands of platinum(II) dichloride complexes, have been recently reported [28,29].

Recently, we have reported the solid-phase synthesis and the pharmacological activity of the first examples of bis-platinated nucleoside complexes in which the mono-functional metal is linked both to $\mathrm{N}-7$ of the purine nucleus of inosine and to the terminal amino-group of a hexylamine side chain installed on N-1 (compounds 1-3, Figure 1) [30]. The amino-alkyl chain was introduced on the purine base system through a chemical strategy recently developed by us [30-36]. These complexes showed very good water solubility thanks to the charged platinum centres and to the ribose hydroxyl groups. They were tested against four different human tumor cell lines and, in particular, the complex bearing two monofunctional cisplatin units was revealed to be more cytotoxic than cisplatin against the MCF7 cancer cell line in a short-term exposure assay [30]. 
Figure 1. Bis-platinated nucleoside complexes synthesized starting from inosine [30].
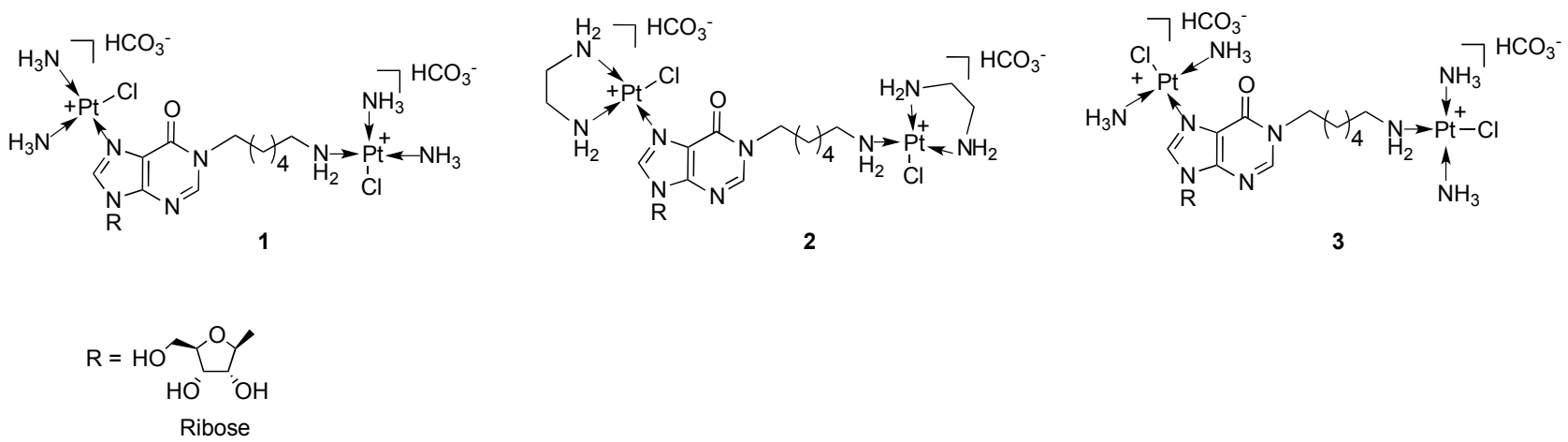

3

In the light of the above results, to investigate the importance of nucleoside scaffolds in the construction of novel platinum complexes we have speculated about the antitumoral activity of cisplatin-adenosine complexes. As a result, in this paper we report on the synthesis of four dinuclear platinum complexes 8a,b and 10a,b (Scheme 1) carrying $N^{6}$-(6-aminohexyl)adenosine (compound 5, Scheme 1) or a 1,6-di-(adenosin- $N^{6}$-yl)-hexane (compound 9, Scheme 1) respectively, as ligands of mono-functional cisplatin or monochloro(ethylene diamine)platinum(II) (compounds $\mathbf{7 a}$ and $\mathbf{7 b}$, respectively, Scheme 1).

Scheme 1. Synthesis of complexes 8 and $\mathbf{1 0 .}$
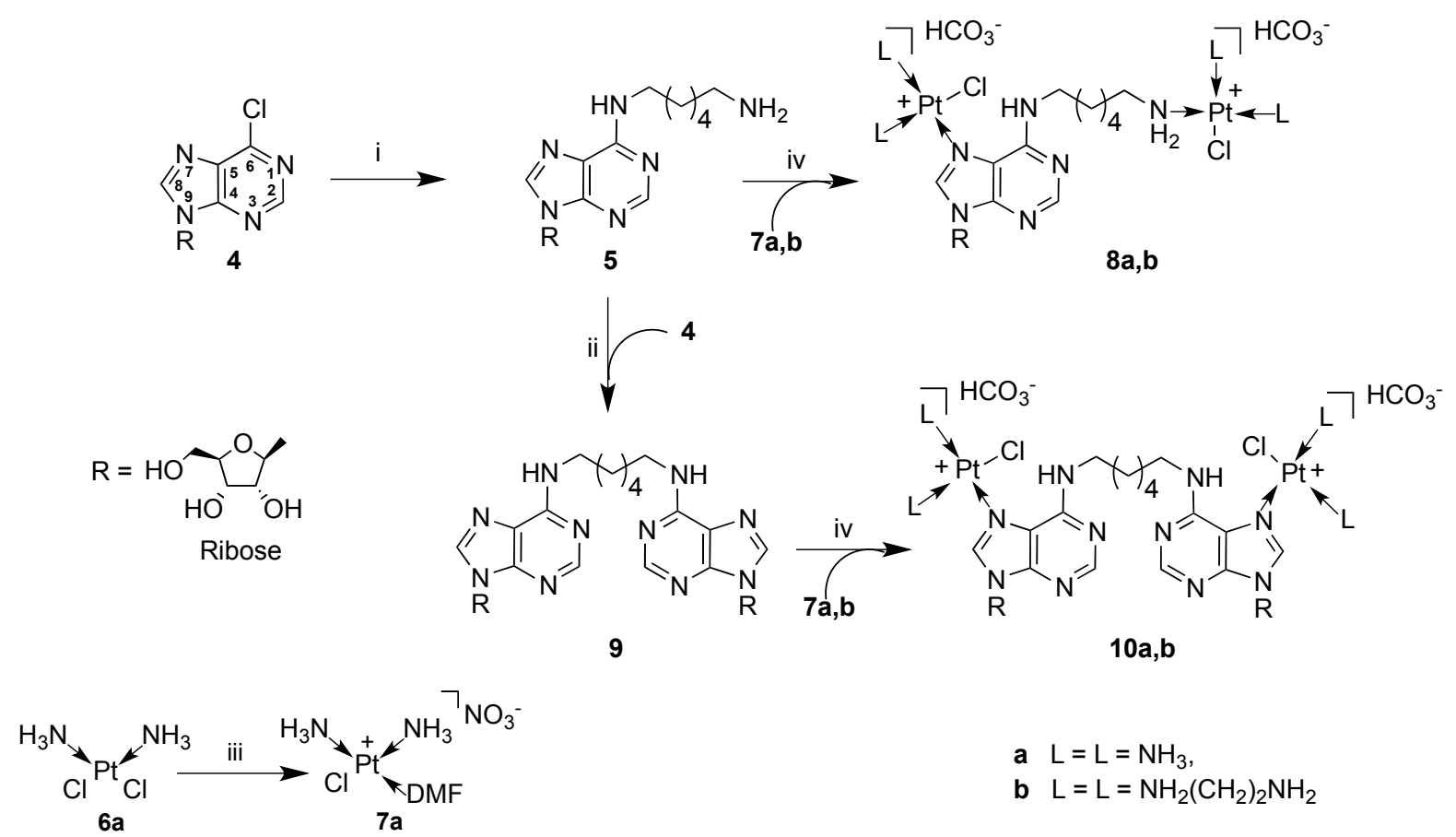

$\begin{array}{ll}\text { a } & \mathrm{L}=\mathrm{L}=\mathrm{NH}_{3}, \\ \text { b } \mathrm{L}=\mathrm{L}=\mathrm{NH}_{2}\left(\mathrm{CH}_{2}\right)_{2} \mathrm{NH}_{2}\end{array}$

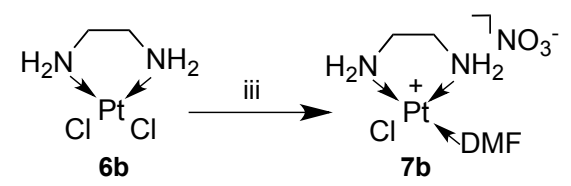

Reagents and conditions: (i) $\mathrm{NH}_{2}\left(\mathrm{CH}_{2}\right)_{6} \mathrm{NH}_{2}$ (7 equiv.), TEA, EtOH, 3 h, reflux; (ii) 4 (1.5 equiv.), TEA, EtOH, 5 h, reflux; (iii) $\mathrm{AgNO}_{3}$ (0.9 equiv.), DMF, 16 h, r.t.; (iv) 7a,b, 16 h, r.t. 
In the case of complexes 8a,b the monofunctional platinum centres are linked to the N-7 of the purine base and to the terminal amino group of a hexylamine side chain bonded to N-6, whereas for the complexes 10a,b they are both linked to N-7.

Platinum complexes, endowed with particular structural strains, have been designed to evaluate alternative interactions with DNA strands [8,12,17,37,38]. The novel prepared complexes $\mathbf{8 a , b}$ and $\mathbf{1 0 a}, \mathbf{b}$ are characterized by a rigid planar purine substructure joined to a flexible hexylamine chain. On this basis, it could be expected that they may alter the binding mode with DNA through, for example, base-stacking or by the formation of multiple hydrogen bonds. Therefore, we have investigated the preliminary effects of these compounds on viability and proliferation in two different human cancer cell lines.

\section{Results and Discussion}

\subsection{Synthesis and Characterization}

The synthesis of the novel modified adenosine-based platinum complexes 8a,b and 10a,b is depicted in Scheme 1. 6-Cloropurine riboside 4 proved to be a good candidate to obtain the key intermediate 5 from which the construction of complexes 8a,b and 10a,b has been accomplished. As reported by Schammells et al. [39] seven equivalents of 1,6-diaminohexane have proved sufficient to convert 4 into 5 in a very good yield (86\%), avoiding the formation of dimeric species, which would complicate the purification procedure. In fact, the recovery of $\mathbf{5}$ from the reaction mixture was easily performed thanks to its insolubility in EtOH upon cooling. Compound 9 was prepared by reacting 4 with a slight excess of $\mathbf{5}$. During the reaction, this substance precipitated from the reaction mixture as a white solid which was then collected in $93 \%$ yield by filtration. This represents a very good improvement on the reported yield for $9(12 \%)$ [40].

Next, the platinum-containing moieties were installed. In particular, treatment of $\mathbf{5}$ and $\mathbf{9}$ with a seven-fold excess of the suitable platinating complex $\mathbf{7 a}, \mathbf{b}$, activated by overnight reaction with $\mathrm{AgNO}_{3}$ (0.9 equiv.) in DMF, furnished the bisplatinated compounds 8a,b and 10a,b. Purification of these substances could be accomplished by reverse-phase HPLC only using a gradient of $\mathrm{CH}_{3} \mathrm{CN}$ in $0.1 \mathrm{M}$ triethylammonium bicarbonate buffer (TEAB) as the solvent mixture, whereas complex chromatographic patterns were observed in the absence of the TEAB.

The structures of complexes $\mathbf{8 a}, \mathbf{b}$ and $\mathbf{1 0 a}, \mathbf{b}$ (yields 58\%-62\%) were supported by 2D-NMR and positive mode high resolution mass spectrometry (HRMS) data; whereas their purity was ascertained by $\mathrm{CHN}$ analyses.

In Figure 2 (panel A) the representative HRMS spectrum of complex 8a is reported; in particular, the isotopic pattern of the base peak (expansion, panel B) perfectly fits with that of the calculated one (expansion, panel $\mathrm{C}$ ), confirming the presence of two $\mathrm{Pt}$ and two $\mathrm{Cl}$ atoms and a net $2+$ charge.

In the ${ }^{1} \mathrm{H}-\mathrm{NMR}$ spectra of $\mathbf{8 a}, \mathbf{b}$ and $\mathbf{1 0 a}, \mathbf{b}$ the downfield shift of $\mathrm{H}-8$, compared with the resonance of the same proton in 5 and $7(\Delta \delta=0.6$ and 0.5 , respectively), confirmed the presence of the $\mathrm{N}(7) \rightarrow$ Pt bond in all these substances [41,42]. In Table 1 the differences between the ${ }^{13} \mathrm{C}$-NMR shifts of the Pt-coordinated and not-coordinated purine carbon atoms $\left(\Delta \delta=\delta_{\text {complex }}-\delta_{\text {ligand }}\right.$, ppm $)$ are listed: in the case of complexes 8a,b significant coordination shifts were found for the C-5 and C-8 atoms, 
whereas for the complexes 10a,b the C-5 atoms underwent the major shifts. Further evidence of metallation at N-7 come from the increased acidity of the H-8 as indicated by the reduced intensity of the pertinent signal in the ${ }^{1} \mathrm{H}-\mathrm{NMR}$ spectra of $\mathbf{8 a}, \mathbf{b}$ and $\mathbf{1 0 a}, \mathbf{b}$, when these complexes were dissolved in $\mathrm{D}_{2} \mathrm{O}$ and the spectra acquired after several hours [43]. ${ }^{1} \mathrm{H}-\mathrm{NMR}$ analyses excluded also the presence of equilibria involving migrations of the platinum moieties from N-7 to N-1 of the nucleobases; such migrations would shift the H-2 resonances of complexes $\mathbf{8 a}, \mathbf{b}$ and $\mathbf{1 0 a}, \mathbf{b}$ to higher frequences in comparison to the same signals of compounds 5 and $\mathbf{9}$, respectively [44]. The resonances of the methylene protons belonging to the $\mathrm{CH}_{2}-\mathrm{NH}_{2}-\mathrm{Pt}$ moieties were seen as broad partly overlapped triplets in the range 2.3-2.7 ppm, in the proton spectra of $\mathbf{8 b}$ and $\mathbf{1 0 b}$, likewise the protons of the methylene group geminal to platinum in $\mathbf{8 a}$ resonated as a triplet at $\delta 2.6$. In ${ }^{13} \mathrm{C}-\mathrm{NMR}$ spectra of $\mathbf{8 a}$ and $\mathbf{8 b}$ the 5 ppm downfield shift of the $\omega$-methylene carbon could be a consequence of the $\mathrm{NH}_{2}$ platination.

Figure 2. HRMS spectrum of complex 8a (panel A). Expansion of the isotopic pattern of the base peak (panel $\mathbf{B}$ ) and of the corresponding calculated one (panel $\mathbf{C}$ ).

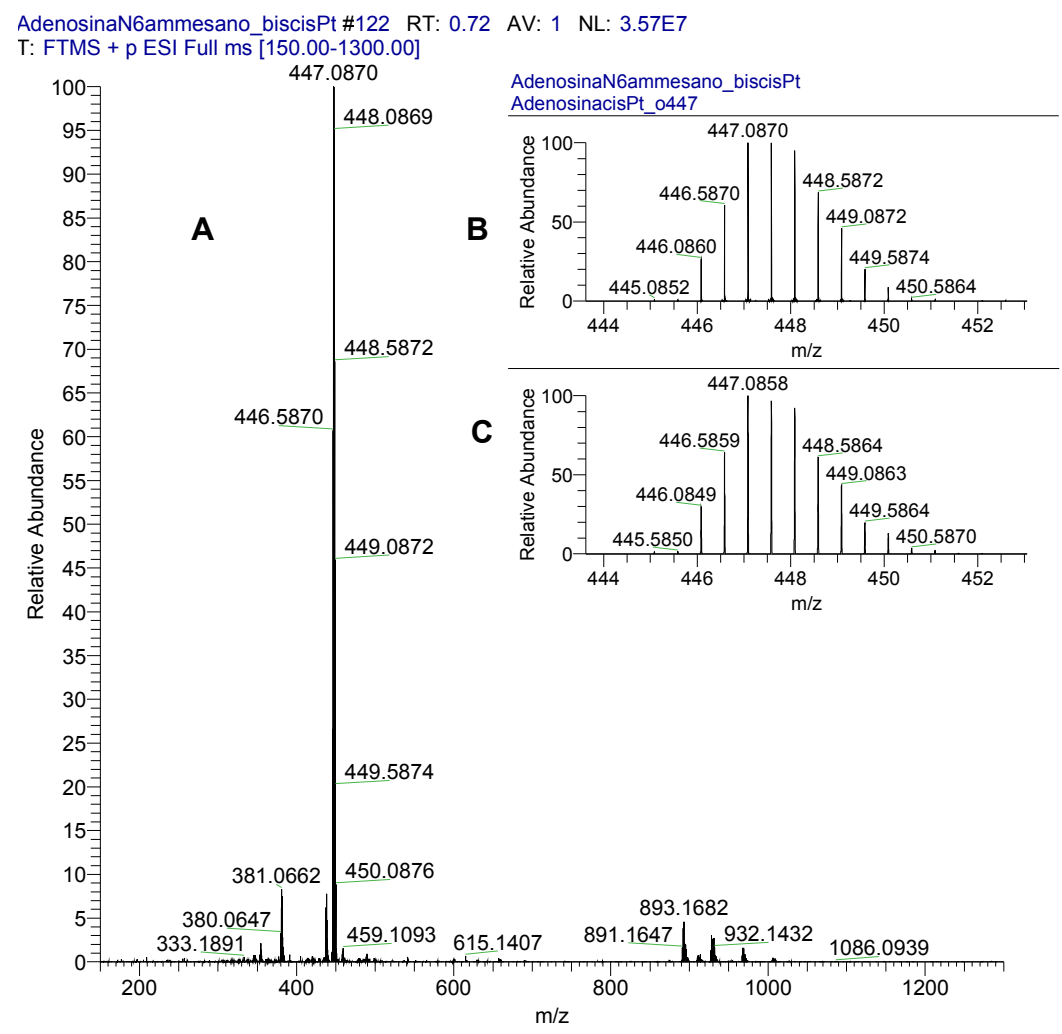

In the UV spectra of the complexes 8a,b and 10a,b the maxima of absorption appeared red-shifted $(\Delta \lambda=10-13 \mathrm{~nm})$ in respect to those of the free ligands, in accordance with literature data [45]. Comparison of the IR spectra of the ligands and complexes did not provide evidence about the bonding mode of the ligands in the complexes; in fact in the $4000-2700 \mathrm{~cm}^{-1}$ region very little information could be obtained about the nature of metal-ligand interaction, because of the presence of broad and intense bands belonging to hydrogen-bonded hydroxyls of the ribose moieties. The $1800-400 \mathrm{~cm}^{-1}$ region, where vibration frequencies of purine and ribose skeletons fall, did not furnish significant differences between platinated and not-platinated nucleosides. Furthermore, in the region $550-400 \mathrm{~cm}^{-1}$, where the resonances of Pt-N could be expected $[45,46]$, no distinctive bands were observed. 
Table 1. Differences between the ${ }^{13} \mathrm{C}-\mathrm{NMR}$ shifts of the Pt-coordinated and not-coordinated purine carbons $\left(\Delta \delta=\delta_{\text {complex }}-\delta_{\text {ligand }}, \mathrm{ppm}\right)$.

\begin{tabular}{cccccc}
\hline \multirow{2}{*}{ Entry } & \multicolumn{5}{c}{${ }^{\mathbf{1 3}} \mathbf{C}-\mathbf{N M R}(\boldsymbol{\Delta} \boldsymbol{\delta}, \mathbf{p p m})$} \\
\cline { 2 - 6 } & $\mathbf{C - 2}$ & $\mathbf{C - 4}$ & $\mathbf{C - 5}$ & $\mathbf{C - 6}$ & $\mathbf{C - 8}$ \\
\hline $\mathbf{8 a}[39]$ & -1.0 & -1.4 & -2.9 & 0.9 & 2.1 \\
$\mathbf{8 b}[39]$ & -1.0 & -1.3 & -2.8 & 0.9 & 2.1 \\
$\mathbf{1 0 a}$ & -1.9 & -2.3 & -4.2 & -0.1 & 0.9 \\
10b & -2.0 & -2.5 & -4.2 & 0.1 & 1.1 \\
\hline
\end{tabular}

\subsection{Cytotoxicity Studies}

The synthesized complexes were subjected to preliminary cell viability and proliferation assays. In particular, the cytotoxic behaviour was studied in A549 adenocarcinomic human alveolar basal epithelial and MCF7 human breast adenocarcinomic cancer cell lines by MTT and BrdU assays, to investigate the potential effects of platinum complexes on cell viability and proliferation, respectively. The incubation of A549 cells with 8a,b and 10a,b (50, 100 and $200 \mu \mathrm{M})$ for $72 \mathrm{~h}$ caused a concentration-dependent reduction of cell survival (Figure 3, panel A) as well as an inhibition of cell proliferation at the higher concentrations (Figure 3, panel B) compared to untreated cells. Indeed, comparable results were obtained when the cell number was directly determined by cell counting (data not shown).

Figure 3. Effect of $\mathbf{8 a}, \mathbf{8 b}, \mathbf{1 0 a}$ and $\mathbf{1 0 b}$ on cell viability and proliferation. A549 cells were incubated with cisplatin, 8a, 8b, 10a and 10b $(50,100$ and $200 \mu \mathrm{M})$ for $72 \mathrm{~h}$. Thereafter, cell viability (panel A) and proliferation (panel B) were determined, respectively, by MTT and BrdU assay as described in the Experimental Section $(* * * p<0.001, * * p<0.01$, $* p<0.05$ vs. untreated cells).

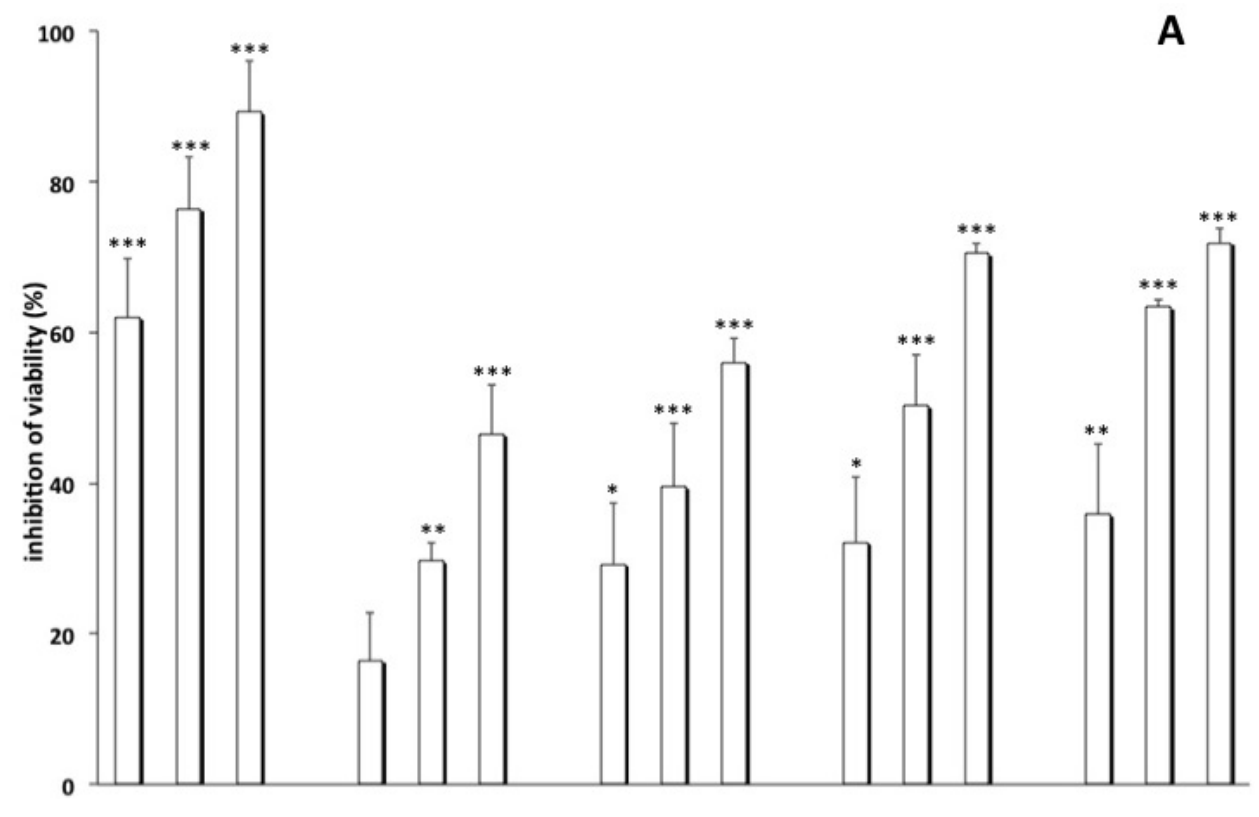


Figure 3. Cont.

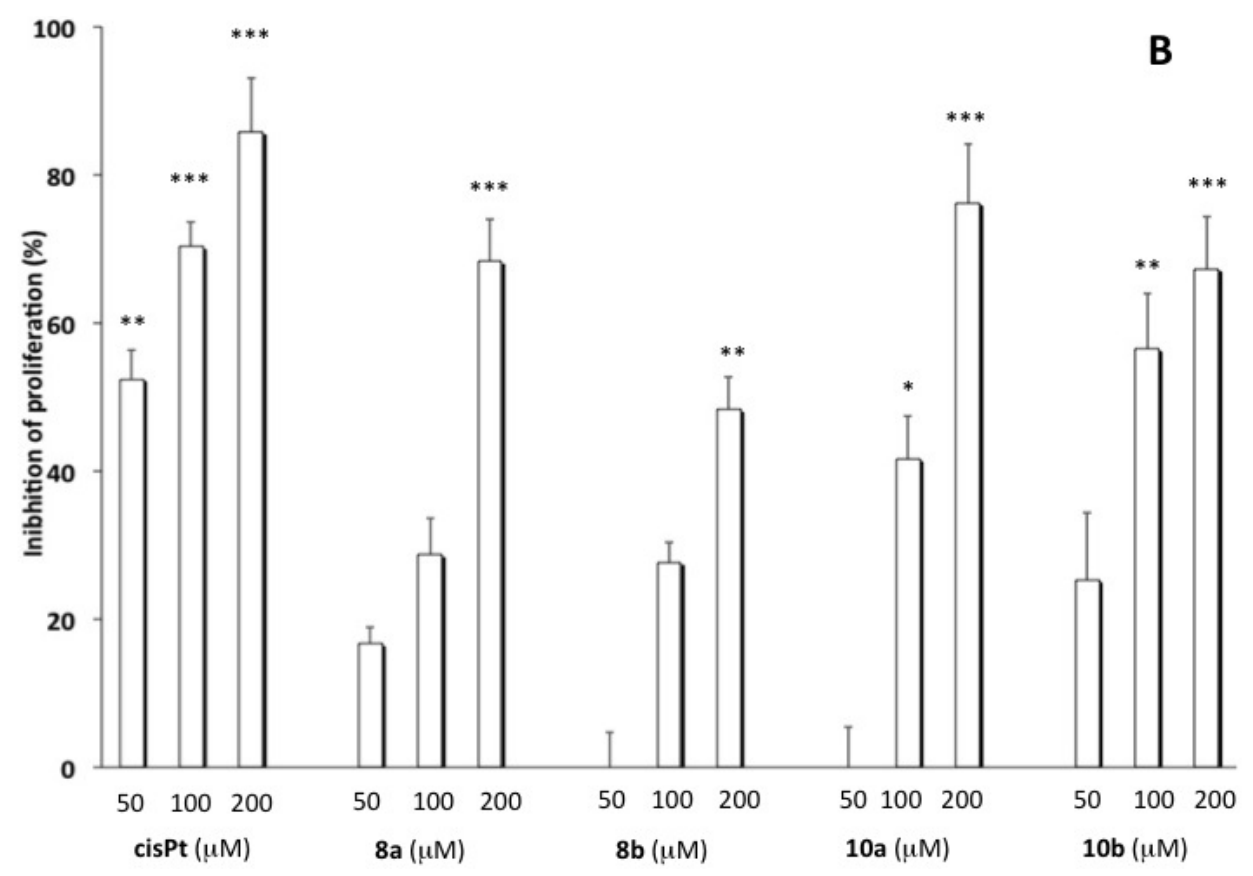

The compounds $\mathbf{8 b}, \mathbf{1 0 a}$ and $\mathbf{1 0 b}(50,100$ and $200 \mu \mathrm{M})$ modified the viability and proliferation of MCF7 cells at higher concentrations, according to the published evidence that these cells have been associated with cisplatin resistance [47]. The compound 8a proved to reduce the proliferation of the MCF7 cell line with a greater ability than the other compounds. Strikingly, compound 8a was able to inhibit the cell proliferation slightly better than cisplatin, but only at $50 \mu \mathrm{M}$ concentration (Figure 4).

Figure 4. Effect of $\mathbf{8 a}, \mathbf{8 b}, \mathbf{1 0 a}$ and $10 \mathbf{b}$ on cell viability and proliferation. MCF7 cells were incubated with cisplatin, 8a, 8b, 10a and 10b $(50,100$ and $200 \mu \mathrm{M})$ for $72 \mathrm{~h}$. Thereafter, cell viability (panel A) and proliferation (panel B) were determined, respectively, by MTT and BrdU assay as described in the Experimental Section $*^{* * *} p<0.001$, ** $p<0.01, * p<0.05$ vs. untreated cells).

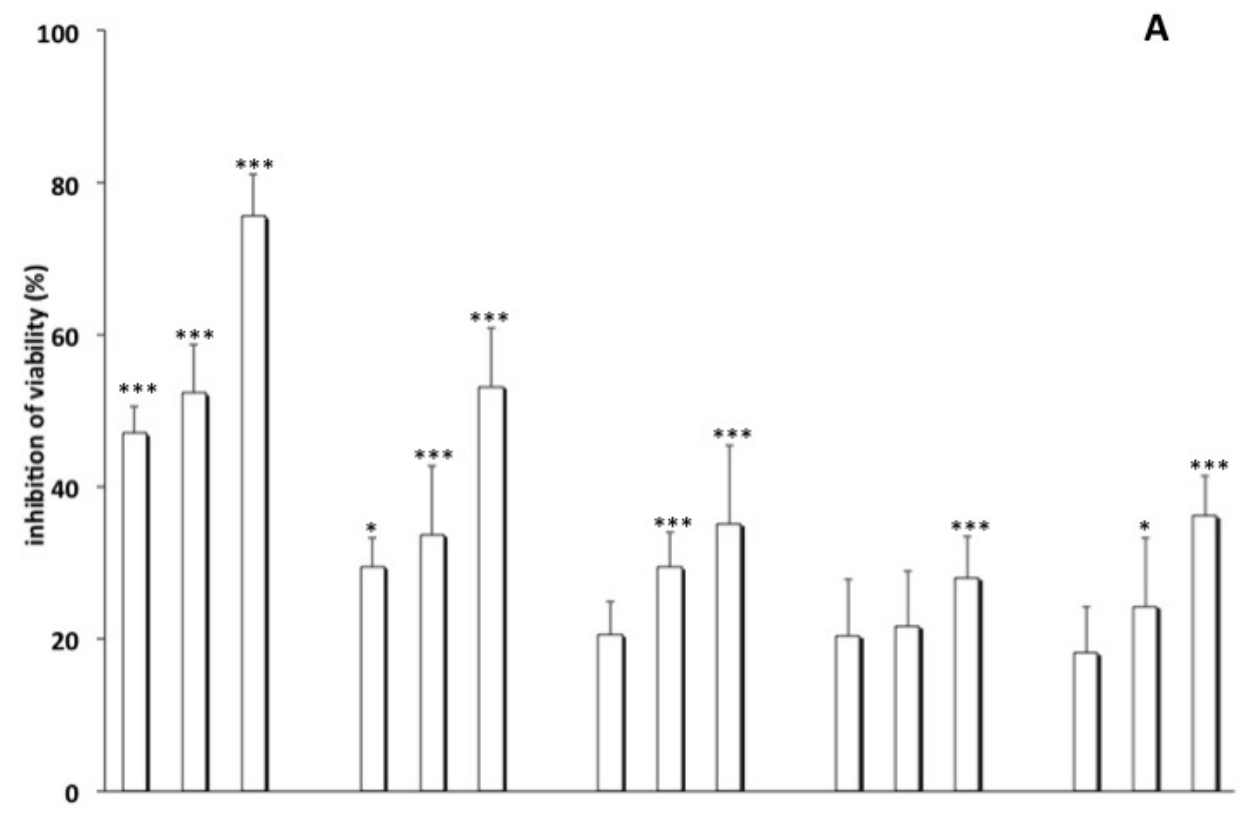


Figure 4. Cont.

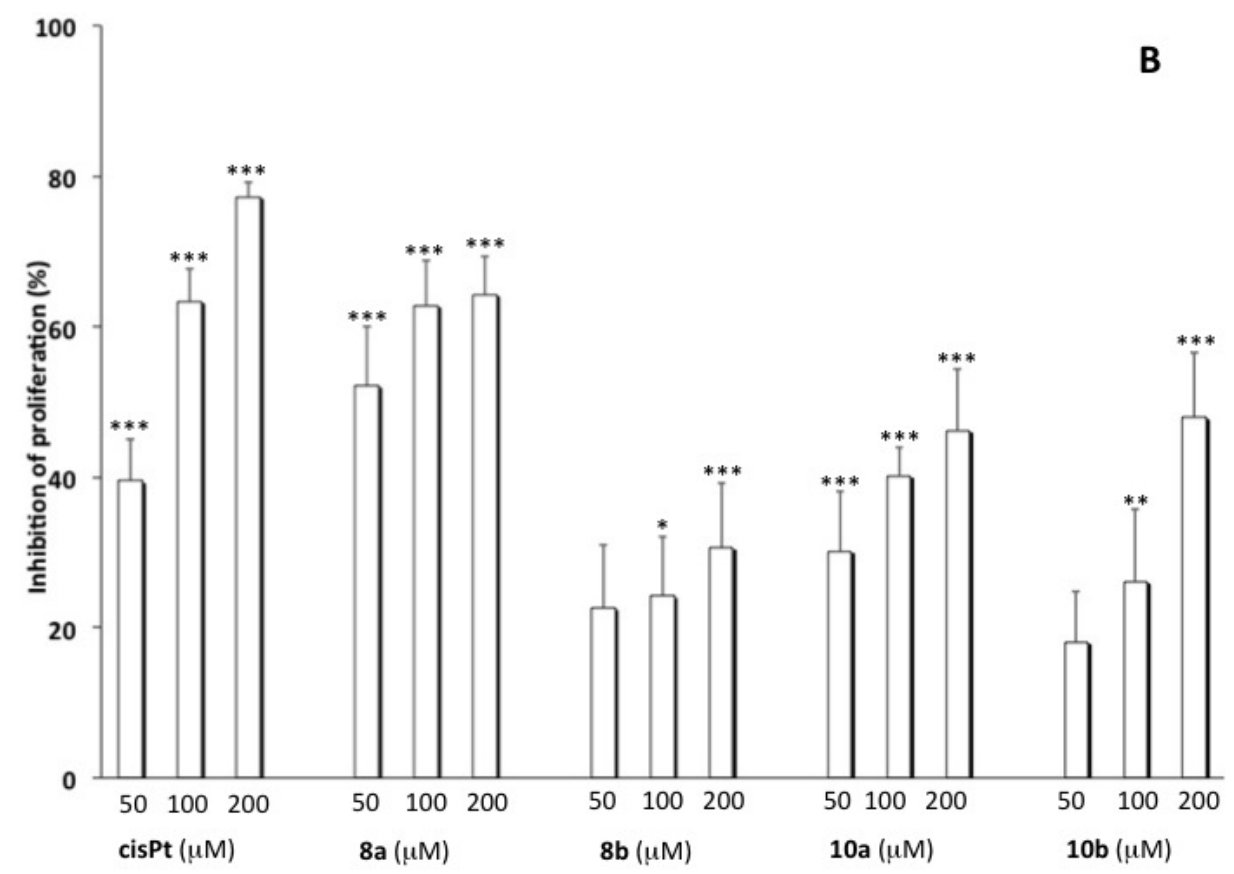

\section{Experimental Section}

\subsection{General Methods}

All the reagents and solvents were obtained from commercial sources and used without further purification. ${ }^{1} \mathrm{H}$ - and ${ }^{13} \mathrm{C}$-NMR spectra were acquired on Varian Mercury Plus $400 \mathrm{MHz}$ instrument using $\mathrm{D}_{2} \mathrm{O}$ or $\left(\mathrm{CD}_{3}\right)_{2} \mathrm{SO}$ as solvents. Chemical shifts were reported in parts per million $(\delta)$ relative to the residual solvent signal $\left({ }^{1} \mathrm{H}\right.$ : HDO $\left.4.80 ;{ }^{13} \mathrm{C}:\left(\mathrm{CD}_{3}\right)\left(\mathrm{CD}_{2} \mathrm{H}\right) \mathrm{SO} 40.4\right)$ and assigned by $2 \mathrm{D}-\mathrm{NMR}$ experiments. UV spectra were recorded on a Jasco V-530 UV spectrophotometer. IR spectra were recorded on a Jasco FT-IR 430 spectrophotometer. High-resolution MS spectra were recorded on a Thermo Orbitrap XL mass spectrometer using the electrospray ionization (ESI) technique in positive mode. Elemental analyses were performed on a Thermo Finnigan Flash EA 1112 CHN analyzer. RP-HPLC analyses and purifications were carried out on a Jasco UP-2075 Plus pump, equipped with a Jasco UV-2075 Plus UV detector, using a C-18 reverse-phase column (5 $\mu \mathrm{m}, 4.8 \times 150 \mathrm{~mm}$ ), eluted with a linear gradient of $\mathrm{CH}_{3} \mathrm{CN}$ in $0.1 \mathrm{M}$ triethylammonium bicarbonate (TEAB) buffer (System A: from $0 \%$ to $50 \%$ in $90 \mathrm{~min}$, flow $1.3 \mathrm{~mL} / \mathrm{min}$, or System B: from $0 \%$ to $100 \%$ in $90 \mathrm{~min}$, flow $1.3 \mathrm{~mL} / \mathrm{min}$ ). Human alveolar basal carcinoma epithelial cells (A549) and human breast cancer cells (MCF7) were grown in Dulbecco's modified Eagle's medium (DMEM) supplemented with 10\% Foetal bovine serum (FBS), $100 \mathrm{U} / \mathrm{mL}$ penicillin and $100 \mathrm{U} / \mathrm{mL}$ streptomycin at $37{ }^{\circ} \mathrm{C}$ under $5 \% \mathrm{CO}_{2}$. The cell lines were all from the ATCC catalogue. All media and supplements for cell culture were purchased from Gibco-Invitrogen (GE Healthcare).

$N^{6}$-(6-Aminohexyl)adenosine (5). Compound 5 (326 mg) was obtained by reaction of 4 (297 $\mathrm{mg}$, $01.04 \mathrm{mmol}$ ) in accordance to the procedure by Schammells et al. [37]. Spectroscopic data and yields were in agreement with those reported by the authors. 
1,6-Di-(adenosin- $N^{6}-y l$ )-hexane (9). Compound 5 (100 mg, $\left.0.27 \mathrm{mmol}\right)$, 6-chloropurine riboside (4, $116 \mathrm{mg}, 0.40 \mathrm{mmol}), \mathrm{Et}_{3} \mathrm{~N}(41 \mu \mathrm{L}, 0.30 \mathrm{mmol})$ were refluxed in EtOH $(1 \mathrm{~mL})$. During the reaction, a colourless solid precipitated from the reaction. After $5 \mathrm{~h}$ it was filtered, washed with boiling EtOH and dried, giving 9 as a colourless powder (164 mg, 93\%). El. An. Calcd. for $\mathrm{C}_{26} \mathrm{H}_{36} \mathrm{~N}_{10} \mathrm{O}_{8}$ : C, 50.64; $\mathrm{H}$, 5.88; N, 22.72. Found: C, 50.68; H, 5.90; N, 22.69. ${ }^{1} \mathrm{H}-\mathrm{NMR}$ and UV data were in agreement with those reported in literature [38]. ${ }^{13} \mathrm{C}-\mathrm{NMR}\left(100 \mathrm{MHz},\left(\mathrm{CD}_{3}\right)_{2} \mathrm{SO}\right) \delta 155.6(\mathrm{C}-2), 153.3(\mathrm{C}-6), 149.1$ (C-4), 140.5 (C-8), 120.7 (C-5), 88.9 (C-1'), 86.9 (C-4'), 74.4 (C-2'), 71.6 (C-3'), 62.6 (C-5'), 40.8 $\left(\mathrm{CH}_{2} \mathrm{NH}\right.$, covered by residual solvent signal), $30.0\left(\mathrm{CH}_{2}\right), 27.1\left(\mathrm{CH}_{2}\right)$; IR (KBr pellet) 3336, 2935, $28611630,1587,1537,1474,1418,1369,1334,1307,1221,1185,1130,1097,1058,985,866,822$, 793, 641, $554 \mathrm{~cm}^{-1} ; m / z 639.2620$ (HRESIMS) ([M + Na] $]^{+}, \mathrm{C}_{26} \mathrm{H}_{36} \mathrm{~N}_{10} \mathrm{NaO}_{8}$, requires 639.2615).

\subsection{General Procedure for the Preparation of Dinuclear Platinum Complexes $\mathbf{8 a , b}$ and $\mathbf{1 0 a}, \mathbf{b}$}

In a representative experiment, cisplatin $(57 \mathrm{mg}, 0.19 \mathrm{mmol})$ was activated by treatment with $\mathrm{AgNO}_{3}(29.0 \mathrm{mg}, 0.17 \mathrm{mmol})$ in DMF $(2 \mathrm{~mL})$ in the dark $(16 \mathrm{~h}$, r.t.). $\mathrm{AgCl}$ was removed by filtration and the resulting solution of $\left[\mathrm{Pt}\left(\mathrm{NH}_{3}\right)_{2}(\mathrm{Cl}) \mathrm{DMF}\right]^{+}\left(\mathrm{NO}_{3}\right)^{-}$in DMF was added to compound 5 (10 mg, $0.027 \mathrm{mmol})$. The solution was shaken in the dark (16 h, r.t.) and then filtered over a GHP Acrodisc $13 \mathrm{~mm}$ syringe filter $(0.45 \mu \mathrm{m}$ GHP membrane). The filter was washed with the minimal amount of DMF and the clarified solution was then subjected to HPLC purification [system A for 8a,b $\left(t_{R}\right.$ : $38.7 \mathrm{~min}$ and $38.4 \mathrm{~min}$ respectively) and system $\mathrm{B}$ for $\mathbf{1 0 a}, \mathbf{b}\left(\mathrm{t}_{\mathrm{R}}: 31.0 \mathrm{~min}\right.$ and $31.5 \mathrm{~min}$ respectively), see General Methods]; the fractions containing the title compound were evaporated under reduced pressure and then lyophilized affording pure 8a.

Compound 8a. Bis-bicarbonate salt (17 mg, 60\%). El. An. Calcd. for $\mathrm{C}_{18} \mathrm{H}_{40} \mathrm{Cl}_{2} \mathrm{~N}_{10} \mathrm{O}_{10} \mathrm{Pt}_{2}$ : C, 21.24; $\mathrm{H}$, 3.96; N, 13.76. Found: C, 21.21; H, 3.98; N, 13.79. ${ }^{1} \mathrm{H}-\mathrm{NMR}\left(400 \mathrm{MHz}, \mathrm{D}_{2} \mathrm{O}\right) \delta 8.84(\mathrm{~s}, 1 \mathrm{H}, \mathrm{H}-8)$, 8.33 (s, 1H, H-2), 6.12 (bs, 1H, H-1'), 4.78-4.76 (m, 1H, H-2', partially covered by solvent signal),

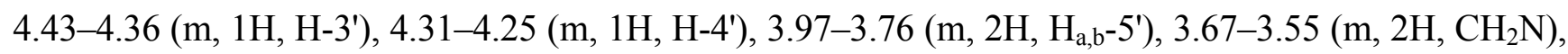
$2.62\left(\mathrm{t}, J=6.4 \mathrm{~Hz}, 1 \mathrm{H}, \mathrm{CH}_{2} \mathrm{NH}_{2} \mathrm{Pt}\right), 1.86-1.72\left(\mathrm{~m}, 2 \mathrm{H}, \mathrm{CH}_{2}\right), 1.71-1.59\left(\mathrm{~m}, 2 \mathrm{H}, \mathrm{CH}_{2}\right), 1.57-1.34$ (complex signal, $\left.4 \mathrm{H}, 2 \times \mathrm{CH}_{2}\right) ;{ }^{13} \mathrm{C}-\mathrm{NMR}\left(100 \mathrm{MHz}, \mathrm{D}_{2} \mathrm{O}\right) \delta 160.2\left(2 \times \mathrm{HCO}_{3}{ }^{-}\right), 153.7(\mathrm{C}-2), 153.2$ (C-6), 146.8 (C-4), 141.6 (C-8), 116.8 (C-5), 89.1 (C-1'), 85.9 (C-4'), 73.9 (C-2'), 70.1 (C-3'), 61.0 $(\mathrm{C}-5 '), 45.7\left(\mathrm{CH}_{2} \mathrm{NH}_{2}\right), 40.7\left(\mathrm{CH}_{2} \mathrm{NH}\right), 29.8\left(\mathrm{CH}_{2}\right), 28.0\left(\mathrm{CH}_{2}\right), 25.4\left(\mathrm{CH}_{2}\right), 25.2\left(\mathrm{CH}_{2}\right)$. IR $(\mathrm{KBr}$ pellet) $3246,2930,1626,1589,1492,1339,1084,1058,835,790,553 \mathrm{~cm}^{-1}$; UV ( $\left.\mathrm{H}_{2} \mathrm{O}\right) \lambda_{\max }=277 \mathrm{~nm}$; HRESI-MS: $(\mathrm{m} / \mathrm{z})$ 447.0870, calcd. $[\mathrm{M}]^{2+} 447.0859$.

Compound 8b. Bis-bicarbonate salt (17 mg, 58\%). El. An. Calcd. for $\mathrm{C}_{22} \mathrm{H}_{44} \mathrm{Cl}_{2} \mathrm{~N}_{10} \mathrm{O}_{10} \mathrm{Pt}_{2}$ : C, 24.70; $\mathrm{H}$, 4.15; N, 13.09. Found: C, 24.73; H, 4.13; N, 13.06. ${ }^{1} \mathrm{H}-\mathrm{NMR}\left(400 \mathrm{MHz}, \mathrm{D}_{2} \mathrm{O}\right) \delta 8.85$ (s, $\left.1 \mathrm{H}, \mathrm{H}-8\right)$, 8.39 (s, 1H, H-2), $6.16\left(\mathrm{~d}, J=5.0 \mathrm{~Hz}, 1 \mathrm{H}, \mathrm{H}-1^{\prime}\right), 4.80(\mathrm{~m}, 1 \mathrm{H}, \mathrm{H}-2$ ', covered by solvent signal), 4.48-4.41 (m, 1H, H-3'), 4.37-4.30 (m, 1H, H-4'), 4.00-3.84 (m, 2H, $\left.\mathrm{H}_{\mathrm{a}, \mathrm{b}}-5^{\prime}\right), 3.78-3.67$ (m, 2H, $\mathrm{CH}_{2} \mathrm{~N}$ ), 2.85-2.50 (complex signal, $10 \mathrm{H}, \mathrm{CH}_{2} \mathrm{NH}_{2} \mathrm{Pt}$ and $4 \times \mathrm{CH}_{2}$ ethylene diamine moieties) 1.91-1.78 (m, 2H, $\left.\mathrm{CH}_{2}\right), 1.77-1.62\left(\mathrm{~m}, 2 \mathrm{H}, \mathrm{CH}_{2}\right), 1.61-1.36$ (complex signal, $\left.4 \mathrm{H}, 2 \times \mathrm{CH}_{2}\right)$; ${ }^{13} \mathrm{C}-\mathrm{NMR}$ $\left(100 \mathrm{MHz}, \mathrm{D}_{2} \mathrm{O}\right) \delta 160.2\left(2 \times \mathrm{HCO}_{3}{ }^{-}\right), 153.7(\mathrm{C}-2), 153.2(\mathrm{C}-6), 146.9(\mathrm{C}-4), 141.6(\mathrm{C}-8), 116.9$ (C-5), 89.1 (C-1'), 85.9 (C-4'), 73.9 (C-2'), 70.1 (C-3'), 61.0 (C-5'), 48.3, 48.0, 47.1 (4 × $\mathrm{CH}_{2}$ ethylene diamine moieties), $45.9\left(\mathrm{CH}_{2} \mathrm{NH}_{2}\right), 40.7\left(\mathrm{CH}_{2} \mathrm{NH}\right), 29.9\left(\mathrm{CH}_{2}\right), 28.1\left(\mathrm{CH}_{2}\right), 25.5\left(\mathrm{CH}_{2}\right), 25.2\left(\mathrm{CH}_{2}\right)$; IR 
(KBr pellet) 3406, 3208, 2931, 1627, 1589, 1470, 1336, 1303, 1232, 1079, 1054, 834, 790, 555, $472 \mathrm{~cm}^{-1}$; UV $\left(\mathrm{H}_{2} \mathrm{O}\right) \lambda_{\max }=278 \mathrm{~nm}$; HRESI-MS: $(\mathrm{m} / \mathrm{z}) 473.1037$, calcd. $[\mathrm{M}]^{2+} 473.1031$.

Compound 10a. Bis-bicarbonate salt (12 mg, 60\%). El. An. Calcd. for $\mathrm{C}_{28} \mathrm{H}_{50} \mathrm{Cl}_{2} \mathrm{~N}_{14} \mathrm{O}_{14} \mathrm{Pt}_{2}$ : C, 26.53 ; H, 3.97; N, 15.47. Found: C, 26.50; H, 3.95; N, 15.45. ${ }^{1} \mathrm{H}-\mathrm{NMR}\left(400 \mathrm{MHz}, \mathrm{D}_{2} \mathrm{O}\right) \delta 8.85(\mathrm{~s}, 2 \mathrm{H}, 2 \times \mathrm{H}-8)$, $8.26(\mathrm{~s}, 2 \mathrm{H}, 2 \times \mathrm{H}-2), 6.14$ (bs, $\left.2 \mathrm{H}, 2 \times \mathrm{H}-1^{\prime}\right), 4.80\left(\mathrm{~m}, 2 \mathrm{H}, 2 \times \mathrm{H}-2^{\prime}\right.$, covered by solvent signal), 4.50-4.40 (m, 2H, $\left.2 \times \mathrm{H}^{\prime} 3^{\prime}\right), 4.38-4.29\left(\mathrm{~m}, 2 \mathrm{H}, 2 \times \mathrm{H}-4{ }^{\prime}\right), 4.03-3.76$ (complex signal, 6H, $2 \times \mathrm{H}_{\mathrm{a}, \mathrm{b}^{-}} 5^{\prime}$ and $\left.2 \times \mathrm{CH}_{\mathrm{a}} \mathrm{N}\right), 3.67-3.53\left(\mathrm{~m}, 2 \mathrm{H}, 2 \times \mathrm{CH}_{\mathrm{b}} \mathrm{N}\right), 1.94-1.75\left(\mathrm{~m}, 4 \mathrm{H}, 2 \times \mathrm{CH}_{2}\right), 1.73-1.51\left(\mathrm{~m}, 4 \mathrm{H}, 2 \times \mathrm{CH}_{2}\right)$; ${ }^{13} \mathrm{C}-\mathrm{NMR}\left(100 \mathrm{MHz}, \mathrm{D}_{2} \mathrm{O}\right) \delta 160.2\left(\mathrm{HCO}_{3}{ }^{-}\right), 153.7$ (C-2), $153.2(\mathrm{C}-6), 146.8(\mathrm{C}-4), 141.4(\mathrm{C}-8), 116.5$ (C-5), 89.1 (C-1'), 85.8 (C-4'), 74.0 (C-2'), $70.0\left(\mathrm{C}^{\prime} 3^{\prime}\right), 61.0\left(\mathrm{C}-5^{\prime}\right), 40.5\left(\mathrm{CH}_{2} \mathrm{NH}\right), 27.8\left(\mathrm{CH}_{2}\right), 25.2$ $\left(\mathrm{CH}_{2}\right)$; IR (KBr pellet) 3280, 2933, 1626, 1589, 1492, 1415, 1339, 1306, 1230, 1085, 1059, 985, 864, $790,552 \mathrm{~cm}^{-1}$; UV $\left(\mathrm{H}_{2} \mathrm{O}\right) \lambda_{\max }=277 \mathrm{~nm}$; HRESI-MS: $(\mathrm{m} / \mathrm{z}) 572.1213$, calcd. $[\mathrm{M}]^{2+} 572.1226$.

Compound 10b. Bis-bicarbonate salt (13 mg, 62\%). El. An. Calcd. for $\mathrm{C}_{32} \mathrm{H}_{54} \mathrm{Cl}_{2} \mathrm{~N}_{14} \mathrm{O}_{14} \mathrm{Pt}_{2}$ : C, 29.12; H, 4.12; N, 14.86. Found: C, 29.15; H, 4.10; N, 14.83. ${ }^{1} \mathrm{H}-\mathrm{NMR}\left(400 \mathrm{MHz}, \mathrm{D}_{2} \mathrm{O}\right) \delta 8.81(\mathrm{~s}, 2 \mathrm{H}, 2 \times \mathrm{H}-8)$, 8.24 (s, 2H, $2 \times \mathrm{H}-2), 6.14$ (bs, $\left.2 \mathrm{H}, 2 \times \mathrm{H}-1^{\prime}\right), 4.80\left(\mathrm{~m}, 2 \mathrm{H}, 2 \times \mathrm{H}-2^{\prime}\right.$, covered by solvent signal), 4.49-4.41 (m, 2H, $\left.2 \times \mathrm{H}^{-3}\right), 4.37-4.31\left(\mathrm{~m}, 2 \mathrm{H}, 2 \times \mathrm{H}-4^{\prime}\right), 4.04-3.83\left(\mathrm{~m}, 4 \mathrm{H}, 2 \times \mathrm{H}_{\mathrm{a}, \mathrm{b}^{-}} 5^{\prime}\right), 3.81-3.60$ $\left(\mathrm{m}, 4 \mathrm{H}, 2 \times \mathrm{CH}_{2} \mathrm{~N}\right), 2.84-2.50$ (complex signal, $8 \mathrm{H}, 4 \times \mathrm{CH}_{2}$, ethylene diamine moieties), 1.95-1.74 $\left(\mathrm{m}, 4 \mathrm{H}, 2 \times \mathrm{CH}_{2}\right), 1.72-1.52\left(\mathrm{~m}, 4 \mathrm{H}, 2 \times \mathrm{CH}_{2}\right) ;{ }^{13} \mathrm{C}-\mathrm{NMR}\left(100 \mathrm{MHz}, \mathrm{D}_{2} \mathrm{O}\right) \delta 160.1\left(\mathrm{HCO}_{3}{ }^{-}\right), 153.6$ (C-2), 153.2 (C-6), 146.6 (C-4), 141.6 (C-8), 116.5 (C-5), 89.1 (C-1'), 85.7 (C-4'), 74.1 (C-2'), 70.1 $\left(\mathrm{C}-3^{\prime}\right), 61.2\left(\mathrm{C}-5^{\prime}\right), 48.1,47.3\left(2 \times \mathrm{CH}_{2}\right.$ ethylene diamine moieties $) 40.5\left(\mathrm{CH}_{2} \mathrm{NH}\right), 27.7\left(\mathrm{CH}_{2}\right), 25.1$ $\left(\mathrm{CH}_{2}\right)$; IR (KBr pellet) 3284, 2930, 1625, 1592, 1490, 1417, 1338, 1310, 1233, 1083, 1061, 980, 860, 791, $554 \mathrm{~cm}^{-1}$; UV ( $\left.\mathrm{H}_{2} \mathrm{O}\right) \lambda_{\max } 276 \mathrm{~nm}$; HRESI-MS: $(\mathrm{m} / \mathrm{z}) 598.1391$, calcd. [M] ${ }^{2+} 598.1382$.

\subsection{MTT Viability Assay}

The cells were plated in 96 culture wells $\left(20 \times 10^{4}\right.$ cells/well $)$ and allowed to adhere overnight. Thereafter, the medium was replaced with fresh medium and the cells were incubated in the absence or presence of cisplatin, 8a, 8b, 10a and $\mathbf{1 0 b}(50,100$ and $200 \mu \mathrm{M})$. After $72 \mathrm{~h}$, the cell viability was determined by using 3-(4,5-dimethylthiazol-2yl)-2,5-diphenyl-2H-tetrazoliumbromide (MTT) conversion assay [48]. Briefly, $10 \mu \mathrm{L}$ of MTT $(5 \mathrm{mg} / \mathrm{mL})$ were added to the cells and incubated for an additional $3 \mathrm{~h}$. After this time point, the cells were lysed and the dark blue crystals solubilized with $150 \mu \mathrm{L}$ of a solution containing 50\% (v:v) DMF, 20\% (w:v) SDS with an adjusted pH of 4.5. The optical density (OD) of each well was measured with a microplate spectrophotometer (Multiskan MCCC/340, Titertek, Huntsville, AL, USA) equipped with a $620 \mathrm{~nm}$ filter. The experiment was performed twice in triplicate. The vitality inhibition, induced by each compound at the indicated concentrations, was expressed as a percentage versus the untreated cells (the control). The viable cells were also counted by the trypan blue exclusion assay and light microscopy.

\subsection{BrdU Cell Proliferation Assay}

The cells were plated onto 96 -well plates $\left(2 \times 10^{4}\right.$ cells/well $)$ overnight. Then, the medium was replaced with fresh medium and the cells were incubated in the absence or presence of cisplatin (50, 
100 and $200 \mu \mathrm{M}), \mathbf{8 a}, \mathbf{8 b}, \mathbf{1 0 a}$ and $\mathbf{1 0 b}(50,100$ and $200 \mu \mathrm{M})$. After $72 \mathrm{~h}, 5$-bromo-2'-deoxyuridine (BrdU; $10 \mu \mathrm{M})$ was added and the cells were cultured for a further $12 \mathrm{~h}$. The mitogenic activity was determined according to the manufacturer's instructions (BrdU cell proliferation assay kit, Cell Signaling). The experiment was performed three times in triplicate. The proliferation inhibition, induced by each compound at the indicated concentrations, was expressed as a percentage versus the untreated cells (the control).

\subsection{Statistical Analysis}

The results are expressed as the means \pm SEM of $\mathrm{n}$ experiments. The statistical significance was calculated by one-way analysis of variance (ANOVA) and Bonferroni-corrected $p$-value for multiple comparison testing. The level of statistically significant difference was defined as $p<0.05$.

\section{Conclusions}

In summary, in this paper we have reported the synthesis of four novel platinum complexes embodying a $N^{6}$-(6-aminohexyl)adenosine or a 1,6-di-(adenosin- $N^{6}$-yl)-hexane as ligands of monofunctional cisplatin or monochloro(ethylene diamine)platinum(II) moieties, starting from commercially available 6-chloropurine riboside. The designed synthetic route allowed us to obtain the desired platinum complexes without blocking the ribose hydroxyl groups and through easy purification steps.

The effects of these platinum complexes on cell viability and proliferation have been studied in A549 and MCF7 cell lines. Our data demonstrate that these compounds are able to inhibit the survival and proliferation of sensitive cancer cells. Nevertheless, cisplatin remains the most active molecule under our experimental conditions. Further experiments are necessary to understand the mechanism by which 8a penetrates into the cells and inhibits cell proliferation in the MCF7 cell line.

\section{Acknowledgments}

This work was financially supported by "Progetto FARO 2011" (Finanziamento per 1'Avvio di Ricerche Originali). We are grateful to Luisa Cuorvo for her technical assistance and to CSIAS (Centro di Servizio Interdipartimentale di Analisi Strutturale) for the NMR facilities.

\section{Author Contributions}

Stefano D'Errico, Brunella Pinto and Fabrizia Nici designed and synthesized the compounds shown in Scheme 1, furthermore Stefano D'Errico wrote the initial draft of the paper and edited the final draft. Vincenzo Piccialli wrote an intermediate draft of the paper and helped write and edit the final draft of the manuscript. Nicola Borbone and Valeria Costantino characterized all the novel platinum complexes, analyzed spectroscopic data from the experiments and wrote the pertinent section in Results and Discussion and in the Experimental Section. Francesca De Falco, Maria Chiara Maiuri and Rosa Carnuccio performed the in vitro biological assays, analyzed and processed the data obtained from the experiments and wrote the pertinent section in the Results and Discussion and in the Experimental Section. Giorgia Oliviero and Gennaro Piccialli supervised all experiments, reanalyzed 
all data for accuracy, and wrote the final draft of the manuscript. All authors reviewed and approved the final version of the manuscript.

\section{Conflicts of Interest}

The authors declare no conflict of interest.

\section{References}

1. Rosenberg, B.; Vancamp, L.; Krigas, T. Platinum compounds: A new class of potent antitumour agents. Nature 1969, 222, 385-386.

2. Kelland, L.R.; Farrell, N. Platinum Based Drugs in Cancer Therapy; Humana Press: Totowa, NJ, USA, 2000.

3. Allardyce, C.S.; Dorcier, A.; Scolaro, C.; Dyson, P.J. Development of organometallic (organo-transition metal) pharmaceuticals. Appl. Organometal. Chem. 2005, 19, 1-10.

4. Wexselblatt, E.; Yavin, E.; Gibson, D. Cellular interactions of platinum drugs. Inorg. Chim. Acta 2012, 393, 75-83.

5. Harper, B.W.; Krause-Heuer, A.M.; Grant, M.P.; Manohar, M.; Garbutcheon-Singh, K.B.; Aldrich-Wright, J.R. Advances in Platinum Chemotherapeutics. Chem. Eur. J. 2010, 16, 7064-7077.

6. Sigel, A.; Sigel, H. Metal Ions in Biological Systems: Metal Complexes in Tumor Diagnosis and as Anticancer Agents; CRC Press: London, UK, 2004.

7. Florea, A.M.; Büsselberg, D. Cisplatin as an Anti-Tumor Drug: Cellular Mechanisms of Activity, Drug Resistance and Induced Side Effects. Cancers 2011, 3, 1351-1371.

8. Fan, D.; Yang, X.; Wang, X.; Zhang, S.; Mao, J.; Ding, J.; Lin, L.; Guo, Z. A dinuclear monofunctional platinum(II) complex with an aromatic linker shows low reactivity towards glutathione but high DNA binding ability and antitumor activity. J. Biol. Inorg. Chem. 2007, 12, 655-665.

9. Boulikas, T. Clinical overview on Lipoplatin ${ }^{\mathrm{TM}}$ : A successful liposomal formulation of cisplatin. Expert Opin. Investig. Drugs 2009, 18, 1197-1218.

10. Abu-Surrah, A.S.; Kettunen, M. Platinum group antitumor chemistry: Design and development of new anticancer drugs complementary to cisplatin. Curr. Med. Chem. 2006, 13, 1337-1357.

11. Arnesano, F.; Natile, G. Mechanistic insight into the cellular uptake and processing of cisplatin 30 years after its approval by FDA. Coord. Chem. Rev. 2009, 253, 2070-2081.

12. Zhang, J.; Wang, L.; Xing, Z.; Liu, D.; Sun, J.; Li, X.; Zhang, Y. Status of Bi- and Multi-Nuclear Platinum Anticancer Drug Development. Anti Cancer Agents Med. Chem. 2010, 10, 272-282.

13. Wheate, N.; Collins, J.G. Multi-nuclear platinum complexes as anti-cancer drugs. Coord. Chem. Rev. 2003, 241, 133-145.

14. Roberts, J.D.; Peroutka, J.; Farrell, N. Cellular pharmacology of polynuclear platinum anti-cancer agents. J. Inorg. Biochem. 1999, 77, 51-57.

15. Pratesi, G.; Perego, P.; Polizzi, D.; Righetti, S.C.; Supino, R.; Caserini, C.; Manzotti, C.; Giuliani, F.C.; Pezzoni, G.; Tognella, S.; et al. A novel charged trinuclear platinum complex effective against cisplatin-resistant tumours: Hypersensitivity of p53-mutant human tumour xenografts. Br. J. Cancer 1999, 80, 1912-1919. 
16. Kasparkova, J.; Zehnulova, J.; Farrell, N.; Brabec, V. DNA interstrand cross-links of the novel antitumor trinuclear platinum complex BBR3464. Conformation, recognition by high mobility group domain proteins, and nucleotide excision repair. J. Biol. Chem. 2002, 277, 48076-48086.

17. Jansen, B.A.J.; Wielaard, P.; Kalayda, G.V.; Ferrari, M.; Molenaar, C.; Tanke, H.J.; Brouwer, J.; Reedijk, J. Dinuclear platinum complexes with N,N'-bis(aminoalkyl)-1,4-diaminoanthraquinones as linking ligands. Part I. Synthesis, cytotoxicity, and cellular studies in A2780 human ovarian carcinoma cells. J. Biol. Inorg. Chem. 2004, 9, 403-413.

18. Mitova, V.; Bogomilova, A.; Shestakova, P.; Momekov, G.; Momekova, D.; Abbas, R.K.; Koseva, N. Synthesis of a new polynuclear platinum (ii) complex and its prodrug forms. Evaluation of their cytotoxic properties. J. Chem. Technol. Metall. 2013, 48, 17-27.

19. Cincinelli, R.; Musso, L.; Dallavalle, S.; Artali, R.; Tinelli, S.; Colangelo, D.; Zunino, F.; de Cesare, M.; Beretta, G.L.; Zaffaroni, N. Design, modeling, synthesis and biological activity evaluation of camptothecin-linked platinum anticancer agents. Eur. J. Med. Chem. 2013, 63, 387-400.

20. Robillard, M.S.; Valentijn, A.; Meeuwenoord, N.J.; van der Marel, G.A.; van Boom, J.H.; Reedijk, J. The First Solid-Phase Synthesis of a Peptide-Tethered Platinum (II) Complex. Angew. Chem. Int. Ed. 2000, 112, 3226-3229.

21. Robillard, M.S.; van Alphen, S.; Meeuwenoord, N.J.; Jansen, B.A.J.; van der Marel, G.A.; van Boom, J.H.; Reedijk, J. Solid-phase synthesis of peptide-platinum complexes using platinum-chelating building blocks derived from amino acids. New J. Chem. 2005, 29, 220-225.

22. Holmes, R.J.; McKeage, M.J.; Murray, V.; Denny, W.A.; McFadyen, W.D. cis-Dichloroplatinum (II) complexes tethered to 9-aminoacridine-4-carboxamides: Synthesis and action in resistant cell lines in vitro. J. Inorg. Biochem. 2001, 85, 209-217.

23. Cai, L.; Lim, K.; Ren, S.; Cadena, R.S.; Beck, W.T. Synthesis and in Vitro Antitumor Activity of Oligonucleotide-Tethered and Related Platinum Complexes. J. Med. Chem. 2001, 44, 2959-2965.

24. Schmidt, K.S.; Boudvillain, M.; Schwartz, A.; van der Marel, G.A.; van Boom, J.H.; Reedijk, J.; Lippert, B. Monofunctionally trans-Diammine Platinum (II)-Modified Peptide Nucleic Acid Oligomers: A New Generation of Potential Antisense Drugs. Chem. Eur. J. 2002, 8, 5566-5570.

25. Butler, J.S.; Sadler, P.J. Targeted delivery of platinum-based anticancer complexes. Curr. Opin. Chem. Biol. 2013, 17, 175-188.

26. Sengupta, P.; Basu, S.; Soni, S.; Pandey, A.; Roy, B.; Oh, M.S.; Chin, K.T.; Paraskar, A.S.; Sarangi, S.; Connor, Y. Cholesterol-tethered platinum II-based supramolecular nanoparticle increases antitumor efficacy and reduces nephrotoxicity. Proc. Natl. Acad. Sci. USA 2012, 109, 11294-11299.

27. Coluccia, M.; Boccarelli, A.; Cermelli, C.; Portolani, M.; Natile, G. Platinum(II)-Acyclovir Complexes: Synthesis, Antiviral and Antitumour Activity. Metal-Based Drugs. 1995, 2, 249-256.

28. Nervi, C.; Vigna, M.A.; Cavigiolio, G.; Ravera, M.; Osella, D. Synthesis and characterization of functionalized thymidine as a potential carrier for cisplatin-like drugs. Inorg. Chim. Acta 2005, 358, 2799-2803.

29. Štarha, P.; Popa, I.; Trávníček, Z.; Vančo, J. N6-Benzyladenosine Derivatives as Novel N-Donor Ligands of Platinum(II) Dichlorido Complexes. Molecules 2013, 18, 6990-7003. 
30. D’Errico, S.; Oliviero, G.; Piccialli, V.; Amato, J.; Borbone, N.; D’Atri, V.; D’Alessio, F.; Di Noto, R.; Ruffo, F.; Salvatore, F.; et al. Solid-phase synthesis and pharmacological evaluation of novel nucleoside-tethered dinuclear platinum (II) complexes. Bioorg. Med. Chem. Lett. 2011, $21,5835-5838$.

31. Oliviero, G.; D’Errico, S.; Borbone, N.; Amato, J.; Piccialli, V.; Piccialli, G.; Mayol, L. Facile Solid-Phase Synthesis of AICAR 5'-Monophosphate (ZMP) and Its 4-N-Alkyl Derivatives. Eur. J. Org. Chem. 2010, 2010, 1517-1524.

32. Oliviero, G.; Amato, J.; Borbone, N.; D’Errico, S.; Piccialli, G.; Bucci, E.; Piccialli, V.; Mayol, L. Synthesis of 4-N-alkyl and ribose-modified AICAR analogues on solid support. Tetrahedron 2008, 64, 6475-6481.

33. Oliviero, G.; D Errico, S.; Borbone, N.; Amato, J.; Piccialli, V.; Varra, M.; Piccialli, G.; Mayol, L. A solid-phase approach to the synthesis of N-1-alkyl analogues of cyclic inosine-diphosphate-ribose (cIDPR). Tetrahedron 2010, 66, 1931-1936.

34. D’Errico, S.; Oliviero, G.; Borbone, N.; Amato, J.; Piccialli, V.; Varra, M.; Mayol, L.; Piccialli, G. Solid-Phase Synthesis of a New Diphosphate 5-Aminoimidazole-4-carboxamide Riboside (AICAR) Derivative and Studies toward Cyclic AICAR Diphosphate Ribose. Molecules 2011, 16, 8110-8118.

35. D’Errico, S.; Oliviero, G.; Borbone, N.; Amato, J.; D’Alonzo, D.; Piccialli, V.; Mayol, L.; Piccialli, G. A Facile Synthesis of 5'-Fluoro-5'-deoxyacadesine (5'-F-AICAR): A Novel Non-phosphorylable AICAR Analogue. Molecules 2012, 17, 13036-13044.

36. D’Errico, S.; Oliviero, G.; Borbone, N.; Amato, J.; Piccialli, V.; Varra, M.; Mayol, L.; Piccialli, G. Synthesis of New Acadesine (AICA-riboside) Analogues Having Acyclic D-Ribityl or 4-Hydroxybutyl Chains in Place of the Ribose. Molecules 2013, 18, 9420-9431.

37. Park, G.Y.; Wilson, J.J.; Song, Y.; Lippard, S.J. Phenanthriplatin, a monofunctional DNA-binding platinum anticancer drug candidate with unusual potency and cellular activity profile. Proc. Natl. Acad. Sci. USA 2012, 109, 11987-11992.

38. Johnstone, T.C.; Alexander, S.M.; Lin, W.; Lippard, S.J. Effects of Monofunctional Platinum Agents on Bacterial Growth: A Retrospective Study. J. Am. Chem. Soc. 2014, 136, 116-118.

39. Gregg, A.; Bottle, S.E.; Devine, S.M.; Figler, H.; Linden, J.; White, P.; Pouton, C.W.; Urmaliya, V.; Scammells, P.J. Dual acting antioxidant A1 adenosine receptor agonists. Bioorg. Med. Chem. Lett. 2007, 17, 5437-5441.

40. Agathocleous, D.C.; Page, P.B.C.; Cosstick, R.; Galpin, J.J.; McLennan, A.G.; Prescott, M. Synthesis of bridged nucleosides. Tetrahedron 1990, 46, 2047-2058.

41. Amo-Ochoa, P.; González, V.M.; Pérez, J.M.; Masaguer, J.R.; Alonso, C.; Navarro-Ranninger, C. Cytotoxicity, DNA binding, and reactivity against nucleosides of platinum (II) and (IV) spermine compounds. J. Inorg. Biochem. 1996, 64, 287-299.

42. Van Rijt, S.; van Zutphen, S.; den Dulk, H.; Brouwer, J.; Reedijk, J. Structure-activity relationship studies for three new asymmetric cis-platinum(II) aminoethanol-based complexes. Inorg. Chim. Acta 2006, 359, 4125-4129.

43. Girault, J.O.; Chottard, G.; Lallemand, J.Y.; Chottard, J.C. Interaction of cis-[Pt( $\left.\left(\mathrm{NH}_{3}\right)_{2}\left(\mathrm{H}_{2} \mathrm{O}\right)_{2}\right]\left(\mathrm{NO}_{3}\right)_{2}$ with ribose and deoxyribose diguanosine phosphates. Biochemistry 1982, 21, 1352-1356. 
44. Arpalahti, J.; Klika, K.D.; Sillanpää, R.; Kivekäs, R. Dynamic processes in platinum(II)-adenosine complexes. Preparation, NMR spectroscopic characterisation and crystal structure of isomeric Pt II (dien)-adenosine complexes. J. Chem. Soc. Dalton Trans. 1998, 1397-1402.

45. Wang, S.; Chu, W.; Wang, Y.; Liu, S.; Zhang, J.; Li, S.; Wei, H.; Zhou, G.; Qin, X. Synthesis, characterization and cytotoxicity of $\mathrm{Pt}(\mathrm{II}), \mathrm{Pd}(\mathrm{II}), \mathrm{Cu}(\mathrm{II})$ and $\mathrm{Zn}(\mathrm{II})$ complexes with 4 '-substituted terpyridine. Appl. Organometal. Chem. 2013, 27, 373-379.

46. Li, L.J.; Wang, C.; Qiao, Y.; Yang, X.Y.; Hua, X.X.; Du, J.L. Platinum(II) complexes of reduced amino acid ester Schiff bases: Synthesis, characterization, and antitumor activity. Res. Chem. Intermed. 2014, 40, 413-424.

47. Fan, S.; Smith, M.L.; Rivet, D.J.; Duba, D.; Zhan, Q.; Kohn, K.W.; Fornace, A.J.; O’Connor, P.M. Disruption of p53 function sensitizes breast cancer MCF-7 cells to cisplatin and pentoxifylline. Cancer Res. 1995, 55, 1649-1654.

48. De Stefano, D.; Tommonaro, G.; Malik, S.A.; Iodice, C.; de Rosa, S.; Maiuri, M.C.; Carnuccio, R. Cacospongionolide and Scalaradial, Two Marine Sesterterpenoids as Potent Apoptosis-Inducing Factors in Human Carcinoma Cell Lines. PLoS One 2012, 7, e33031.

Sample Availability: Samples of the compounds $\mathbf{8 a}, \mathbf{b}$ and $\mathbf{1 0 a}, \mathbf{b}$ are available from the authors.

(C) 2014 by the authors; licensee MDPI, Basel, Switzerland. This article is an open access article distributed under the terms and conditions of the Creative Commons Attribution license (http://creativecommons.org/licenses/by/3.0/). 